\title{
Morphological and Histological Study of White Rats (Rattus norvegicus) Kidney Following the Consumption of Sumatran Wild Mango Extract (Mangifera spp.)
}

\author{
Fitmawati ${ }^{1, *}$ Agus Saputra ${ }^{1}$ Sri Nur Kholifah ${ }^{1}$ Esi Resida ${ }^{1}$ Rodesia Mustika \\ Roza $^{1}$ Emrizal $^{2}$ \\ ${ }^{1}$ Department of Biology, Faculty Mathematics and Natural Sciences, Riau University, Pekanbaru 28293, \\ Indonesia \\ ${ }^{2}$ School of Riau Pharmacy, Pekanbaru 28293, Indonesia \\ * Corresponding author. Email: fitmawati2008@yahoo.com
}

\begin{abstract}
The development of medicine requires preclinical testing of experimental animals. One of the potential plants to be developed as a new medicinal source is Sumatran wild mangoes (Mangifera spp.) which are known to have immunomodulatory activity and higher antioxidant value than cultivated Mangifera. This study was aimed to test the sub-chronic toxicity of the extract of 6 wild mango species on white rats' kidney function. This study used 21 treatments and 3 replications, consisted of 3 control treatments (control 0, with distilled water, positive control (stimuno) and negative control (CMC-Na 1\%), and 6 types of Mangifera spp. (Mangifera sp.2 (Hutan), M. sumatrana, M. foetida (var. Batu, Limus, and Manis), and M. laurina) with 3 different dosages. Observations were made macroscopically (morphology) and histology through the glomerulus image to see the percentage of damage. The percentage of glomerulus damage was analyzed by ANOVA and Duncan's test. Based on the results showed that the kidney morphology looked like a pea with brownish-red color and the capsule looked flat (healthy) after being treated. Histologically, the administration of wild mango extract did not cause damage to the rats' kidneys, which was indicated by the glomerulus which was still covered by the bowman capsule and the boundary between the pars visceral epithelium and pars parietal epithelium was clearly visible.
\end{abstract}

Keywords: Development herbal medicine, glomerulus, Mangifera spp., toxicity

\section{INTRODUCTION}

Preclinical testing is absolutely carried out in the process of developing plants as ingredients for herbal medicines. Evaluation of the safety and possible side effects of a substance needs to be done, especially on vital organs such as the kidneys, which serve as filtration of all fluids in the body. The kidney is an organ that often receives side effects from administering a drug, especially toxicity to the nephron [1]. The high volume of blood flow concentrates the toxicity on filtration, carries the toxin through the tubular cells, and activates the toxin, thus making the kidneys the target organs for toxic effects [2], [3].

Toxicity testing in animals is useful to see if there are biochemical, physiological, and pathological reactions that may occur before use in humans [4]. One of the plants that are reported to have the potential to be developed is some wild mangoes from Sumatra. Its high anti-oxidant content has the ability as an immunomodulator [5]. Plants have long been a source of exogenous antioxidants. Two-thirds of the plant species in the world play important roles in medicine Plants that contain antioxidant compounds have a very important role to increase immunity in the body [6].

Fitmawati [7] has isolated compounds from wild Sumatran mangoes. Mangifera sp.1 (MBS) species had the highest antioxidant, phenolic, and flavonoid values in the leaves and bark, followed by $M$. foetida 3 (type. Batu), M. torquenda, and M. sumatrana. $M$. laurina has the highest quercetin content in its leaves compared to other wild mango species. Quercetin is a 
polyphenol derivative, a major antioxidant, which protects against cell damage from free radicals, DNA damage, and other degenerative diseases [8-10]. This information supports the future development of wild mango and its prospects as a new medicinal source.

However, to be developed as a drug, it is necessary to prove the safety of wild mangoes through toxicity tests on the kidney organs. This study aimed to determine the sub-chronic toxic effects of wild mango on rat kidney organs. The results are expected to support the development of herbal medicine in the community.

\section{MATERIALS AND METHODS}

This study used a randomized block design with 21 treatments and 3 replications, consisted of 3 control treatments (Control 0 with distilled water, positive control (stimuno) and negative control (CMC $\mathrm{Na} \mathrm{1 \% )}$ and 6 types of ethanol leaves extract from Mangifera sp.2 (mangga hutan), M. sumatrana, $M$. foetida (var. Batu, var. Limus, and var. Manis), and M. laurina at doses of $1 \mathrm{ppm}, 10 \mathrm{ppm}$ and $1000 \mathrm{ppm}$ were given orally for 7 days. Observation of the kidney carried out by morphological and histological structure by calculating the percentage of damage [11]. The data analyzed using ANOVA, with the continued test of the Duncan Multiple Range Test (DMRT) with the SPSS for Windows program [12].

\section{RESULT AND DISCUSSION}

The kidneys are vital organs that regulate acidbase balance, electrolyte fluid, and osmolarity. The regulation of excretory substances and disposal of metabolic waste is carried out by the kidneys so that damage to the kidneys often occurs as a result of the use of certain drugs, especially the nephron [13]. This study conducted a subchronic oral toxicity test, which is a test to detect the presence of toxic effects that arise after giving repeated doses of wild mango extracts orally [14]. Subchronic toxicity testing in rats' kidneys was carried out by observing and calculating the presentation of renal glomerular damage on renal histology and morphology.

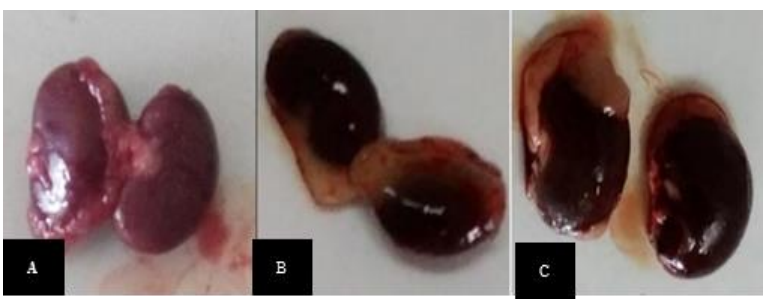

Figure 1. Macroscopic Structure of the Kidney of White Rats ( $R$. norvegicus). A: Normal Control, B: Positive Control, C: Negative Control.
Observation of kidney morphology was carried out by comparing control treatments. Observations of the kidney organ morphology of white rats in the control treatment (normal control, positive control, and negative control) showed that the kidney organ was shaped like a pea, brownish-red and the capsule looked flat (no change). The upper and lower parts of the kidneys of white rats appear convex, while those of the medal edges of the kidneys appear concave due to the presence of a hilar, which is the entry point for a blood vessel, lymph vessels, nerves, and ureters that enter and leave the kidney. Based on Figure 1, there is no change in the macrostructure of the kidney because the kidney for each treatment looked normal and healthy.

Figures 2 and 3 show the kidney organs treated with the ethanol extract of the leaves of 6 types of wild mango Sumatra (Mangifera spp.). Observation of kidneys morphology had a brownish-red color with a bean-like shape. In all treatments, it showed that the kidneys looked normal and healthy, this was following the normal and positive control treatments (Figure 1). The Provision of wild mangoes extract did not give a toxic effect on the morphology of the rat kidney. Normal kidney organs are shaped like beans and brownish-red color.

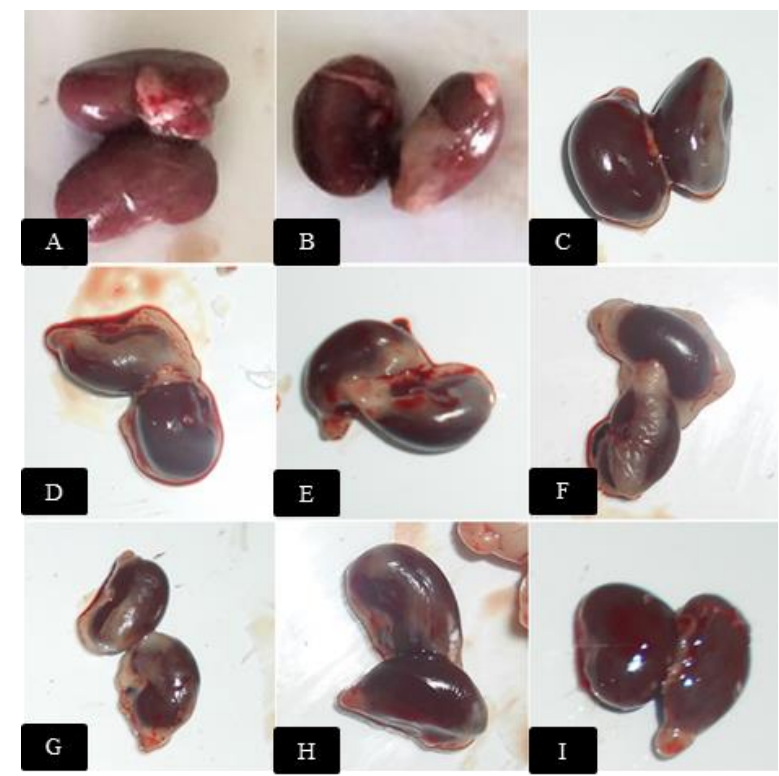

Figure 2. Macroscopic Structure of the Kidney of White Rats ( $R$. norvegicus). A: Mangifera sp.2 (MH) dose 1, B: Mangifera sp.2 (MH) dose 2, C: Mangifera sp.2 (MH) dose 3, D: M. sumatrana dose 1, E: M. sumatrana dose 2, F: . sumatrana dose 3, G: $M$. foetida (var. Batu) dose 1, H: M. foetida (var. Batu) dose 2, I: $M$. foetida (var. batu) dose 3 


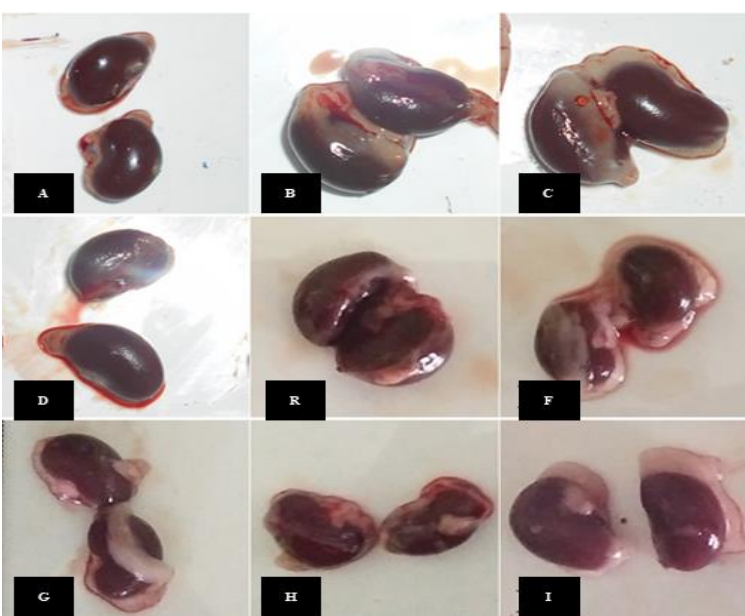

Figure 3. Macroscopic Structure of the Kidney of White Rats ( $R$. norvegicus) A: $M$. foetida (var. limus) dose 1, B: (M. foetida (var. Limus) dose 2, C: (M. foetida (var. limus) dose 3, D: M. foetida (var. manis) dose 1, E: M. foetida (var. manis) dose 2, F: $M$. foetida (var. manis) dose 3, G: M. laurina dose 1, $\mathbf{H}$ : M. laurina dose 2, I: M. laurina dose 3 .
The upper and lower parts of the kidneys in the treatment was convex and concave at the edges of the medal. The upper and lower parts of the kidneys of white rats appear convex, while the medal edges of the kidneys appear concave due to the discovery of the hilar $[15,16]$. Kidney's texture and color are parameters needed to be observed in this study because the kidneys are sensitive organ to toxic exposure. The macroscopic observation results of the rats' kidneys in the control and giving ethanol extract treatment of six types of mango leaves with three treatments are presented in Table 1.

Kidney color character using the Munsell color table shows that the difference in color from each treatment. The table 1 shows that the kidneys color of the white rats for each treatment have the same color group, namely 5R. However, the difference in the color of the white rats' kidneys from each treatment was in the $5 \mathrm{R}$ color sub-color based on the Munsell color table.

Table 1. Macroscopic picture of rats' kidneys in the control and giving ethanol extract treatment of six types of mango leaves with three variations of doses

\begin{tabular}{|c|c|c|c|}
\hline & & Color & Texture \\
\hline \multirow{3}{*}{ Control } & Aquadest (K0) & 5R; Dp.4 & Elastic, Smooth \\
\hline & Stimuno $(\mathrm{K}+)$ & 5R; Dk.1 & Elastic, Smooth \\
\hline & CMC Na 1\% (K-) & 5R; Dgr & Elastic, Smooth \\
\hline \multirow{3}{*}{ Mangifera sp.2(MH) } & D1 (1 ppm) & 5R; Dl.1 & Elastic, Smooth \\
\hline & D2 (10 ppm) & 5R; Dl.3 & Elastic, Smooth \\
\hline & D3 (100 ppm) & 5R; Dk.2 & Elastic, Smooth \\
\hline \multirow{3}{*}{ M. sumatrana } & D1 (1 ppm) & 5R; D1.2 & Elastic, Smooth \\
\hline & D2 (10 ppm) & 5R; D1.2 & Elastic, Smooth \\
\hline & D3 (100 ppm) & 5R; Dk.1 & Elastic, Smooth \\
\hline \multirow{3}{*}{ M. foetida (var. batu) } & D1 (1 ppm) & 5R; Dl.2 & Elastic, Smooth \\
\hline & D2 (10 ppm) & 5R; Dk.2 & Elastic, Smooth \\
\hline & D3 (100 ppm) & 5R; Dp.1 & Elastic, Smooth \\
\hline \multirow{3}{*}{ M. foetida (var. limus) } & D1 (1 ppm) & 5R; Dk.2 & Elastic, Smooth \\
\hline & D2 (10 ppm) & 5R; Dk.1 & Elastic, Smooth \\
\hline & D3 (100 ppm) & 5R; Dk.2 & Elastic, Smooth \\
\hline \multirow{3}{*}{ M. foetida (var. manis) } & D1 (1 ppm) & 5R; Gr.2 & Elastic, Smooth \\
\hline & D2 (10 ppm) & 5R; D1.2 & Elastic, Smooth \\
\hline & D3 (100 ppm) & 5R; Dl.4 & Elastic, Smooth \\
\hline \multirow{3}{*}{ M. laurina } & D1 (1 ppm) & 5R; Dl.1 & Elastic, Smooth \\
\hline & D2 (10 ppm) & 5R; Dl.4 & Elastic, Smooth \\
\hline & D3 (100 ppm) & 5R; Dl.1 & Elastic, Smooth \\
\hline
\end{tabular}


Then the texture of the rats' kidneys in each treatment all had a chewy organ texture with a smooth organ surface. The next parameter of toxicity testing is kidney histology. The histopathological changes observed is the swelling that occurred in the glomerular cells of the rat kidney. In this study, observations made in the form of abnormal glomerular cell percentage. The percentage of damage data and the scoring of damage that occurred in glomerular cells are presented in Table 2. The results of the ANOVA test, the percentage of damage to the glomerular renal cells of white rats in each treatment with three variations of the dose, obtained a P-value of 0.000 . P-value $<0.05$, which means that there is a significant percentage of glomerular cell damage in each treatment with three dose variations. The DMRT test results showed a significant difference between the control treatment and the ethanol extract treatment of six types of mango leaves with three variations of doses. Meanwhile, the extracts of 6 types of mango did not show significant differences between treatments. The percentage of damage calculation table is shown in the following Table 2 .

Table 2 shows that the lowest mean percentage of glomerular cell damage was the treatment in the positive control (Stimuno) of $1.133 \pm 0.148$. The damage that occurred in the kidney glomerulus of positive control rats was still within normal limits. Meanwhile, the highest mean percentage of glomerular cell damage occurred in negative controls (CMC Na $1 \%$ ) of $28.422 \pm 2.598$. In this negative control, the damage that occurred in the renal glomerulus of white rats was in the category of mild damage.

Table 2. White Rat Kidney Glomerular Cell Damage and Scoring

\begin{tabular}{|c|c|c|c|}
\hline \multicolumn{2}{|c|}{ Treatments } & \multirow{2}{*}{$\begin{array}{c}\begin{array}{c}\text { Average Percentage of } \\
\text { Damage }\end{array} \\
7,488 \pm 1,133^{\mathrm{b}}\end{array}$} & \multirow{2}{*}{$\begin{array}{c}\text { Damage Scoring } \\
0\end{array}$} \\
\hline \multirow{3}{*}{ Control } & Aquadest (K0) & & \\
\hline & Stimuno $(\mathrm{K}+)$ & $1,133 \pm 0,148^{\mathrm{a}}$ & 0 \\
\hline & CMC Na $1 \%(\mathrm{~K}-)$ & $28,422 \pm 2,598^{\mathrm{g}}$ & 1 \\
\hline \multirow{3}{*}{ Mangifera sp.2 (Hutan) } & D1 (1 ppm) & $13.897 \pm 1.276^{\text {cde }}$ & 0 \\
\hline & $\mathrm{D} 2(10 \mathrm{ppm})$ & $13.395 \pm 1.788^{\text {cde }}$ & 0 \\
\hline & D3 (100 ppm) & $13,028 \pm 1,413^{\text {cde }}$ & 0 \\
\hline \multirow{3}{*}{ Mangifera sumatrana } & D1 (1 ppm) & $12.135 \pm 0.416^{\mathrm{cd}}$ & 0 \\
\hline & D2 (10 ppm) & $11.753 \pm 0.884^{\mathrm{cd}}$ & 0 \\
\hline & D3 (100 ppm) & $15.633 \pm 1,418^{\mathrm{e}}$ & 0 \\
\hline \multirow{3}{*}{ Mangifera foetida (var. Batu) } & D1 (1 ppm) & $14.359 \pm 1.026^{\mathrm{de}}$ & 0 \\
\hline & D2 (10 ppm) & $12.098 \pm 0.068^{\mathrm{cd}}$ & 0 \\
\hline & D3 (100 ppm) & $13.429 \pm 1.524^{\text {cde }}$ & 0 \\
\hline \multirow{3}{*}{ Mangifera foetida (var. Limus) } & D1 (1 ppm) & $13,819 \pm 2,526^{\text {cde }}$ & 0 \\
\hline & $\mathrm{D} 2(10 \mathrm{ppm})$ & $18,767 \pm 2,383^{\mathrm{f}}$ & 0 \\
\hline & D3 (100 ppm) & $12,748 \pm 1.082^{\text {cd }}$ & 0 \\
\hline \multirow{3}{*}{ Mangifera foetida (var. Manis) } & D1 (1 ppm) & $13,573 \pm 1.260^{\text {cde }}$ & 0 \\
\hline & D2 (10 ppm) & $14,4084 \pm 1.148^{\text {cde }}$ & 0 \\
\hline & D3 (100 ppm) & $11.519 \pm 0.408^{c}$ & 0 \\
\hline \multirow{3}{*}{ Mangifera laurina } & D1 (1 ppm) & $11.378 \pm 0.231^{\mathrm{c}}$ & 0 \\
\hline & D2 (10 ppm) & $12,988 \pm 0,845^{\text {cde }}$ & 0 \\
\hline & D3 (100 ppm) & $20.406 \pm 1.487^{f}$ & 0 \\
\hline
\end{tabular}

Note: Damage Scoring 0: Normal, 1: Light, 2: Moderate, 3: Heavy. D1: Dose 1, D2: Dose 2, D3: Dose 3. The numbers followed by different letters in the same column are significantly different at the $5 \%$ confidence level. 


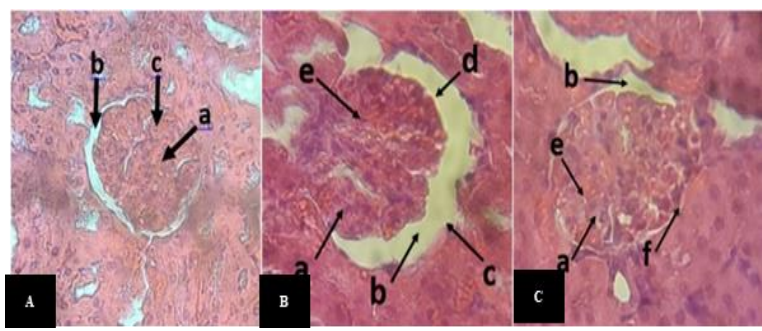

Figure 4. Histologic Structure of the White Rat $(R$. novergicus) kidney. Hematoxylin-Eosin Staining. Magnification 400x. A: Normal Control, B: Control

In the control treatment, the percentage of renal glomerular cell damage in white rats was $7.488 \pm$ $1.133 \%$ and it is still within the limits of damage that occurs in normal white rat kidney glomerulus. The damage value for control should be $0 \%$. This is caused by several factors, including external factors that cannot be controlled, such as the psychological state and the initial condition of the white rat kidney before being given treatment [17]. This situation can also be caused by the increased activity of cytosolic enzymes due to white rats under stress that effect on the kidneys and heart [18].

Figure 4 shows the histological structure of the kidney of white rats with control treatment, positive and negative control with three dose variations. Based on the picture, it shows that the renal glomerulus of white rats in control and positive control looks normal. This is characterized by the glomerular structure of the down man space that is visible. The boundary between the epithelium pars visceral and epithelium pars parietal can be distinguished and visible the boundary between the two epitheliums.

Besides, the glomerular cells in these two controls look normal with the characteristics of polyhedral cells, round nuclei, and located inside the cell. Normal glomerulus has characteristics including being covered by a bowman capsule, polyhedral cells, round nuclei and inside the cell, clear cytoplasm, and the boundary between the par's visceral epithelium and the pars parietal epithelium are visible $[19,20]$. In the negative control, it showed renal glomerulus found several damages to the glomerular cells and in the category of minor damage. In the negative control, there is a marked increase in renal glomerular swelling of the white rats. This is because the pars visceral and pars parietal epithelium fuse together so that they can't be distinguished (Figure 4).

According to Susilo \& Ismail [21], kidney damage caused by toxic substances shows a microscopic picture of degeneration symptoms which can then lead to other forms of damage in the form of necrosis. The administration of ethanol extract of six types of wild mango leaves (Mangifera spp.) Dose 1, dose 2, and dose 3 showed the percentage of glomerular damage are lower than the negative control treatment $(28.422 \pm 2.598)$. Based on the percentage value, the higher the dose given, the lower the damage to the glomerulus of white rats. This can be seen from the percentage of damage in the extracts of Mangifera sp.2 (Hutan) and Mangifera foetida (var. Batu, Limus, and Manis) showing that high doses can reduce the percentage of damage. The damage that occurs at higher doses indicates a value that is still within normal limits, the damage that occurs to the kidneys is less than $25 \%$. The renal glomerulus of white rats in this treatment was still covered by Bowman's capsule which was marked by the boundary between the visceral pars epithelium and the pars parietal epithelium visible (Figures 5 and 6).

Besides, glomerular cells are polyhedral with a moon-shaped nucleus. However, some damage was still found including necrosis, fat degeneration, and hydropic degeneration in each treatment. Necrosis can be triggered by other damage that occurs in cells such as fatty and hydropic degeneration and is characterized by disappearing cell nuclei, increased eosinophils, and can be triggered by external factors $[22,23]$.

Mangifera sumatrana and M. laurina showed that the low dose had a small percentage of damage, namely $11,753 \pm 0.884$ (dose 2 ) and 11,378 \pm 0.231 (dose 1), respectively. These countermeasures with the renal glomerulus of the treated rats are covered by Bowman's capsule. Cells appear to be polyhedral with a round nucleus. The boundary between the epithelium pars visceral and epithelium pars parietal is clearly visible. The kidneys act as a organ for the filtration of substances that enter the body through the circulatory system. One part of the kidney that does this filtering is the glomerulus. When capillary permeability and filtration processes increase in the glomerulus it can cause leakage of plasma proteins and erythrocytes. This can result in damage to the glomerular filtration membrane and swelling and edema in the bowman space, causing a narrowing in the bowman space [24].

An enlarged glomerulus due to increased glomerular volume can cause the narrowing of the bowman space. This damage can disrupt the function of filtrate production and filtrate control. Besides, the glomerulus is one part that is easily exposed to low circulating toxins compared to other tissues found in the kidneys [12]. 


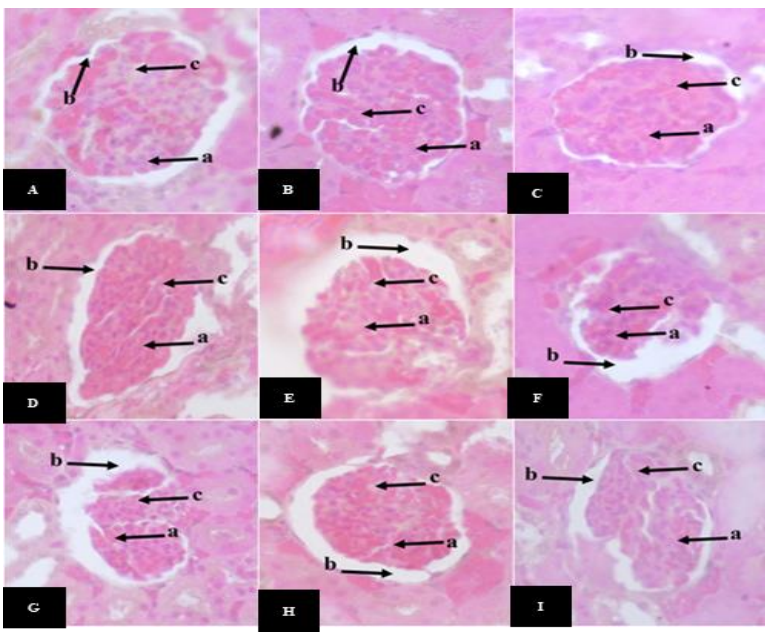

Figure 5. Histologic Structure of the White Rat $(R$. novergicus) kidney. Hematoxylin-Eosin Staining. Magnification 400x. A. Mangifera sp.2 (Hutan) dose 1; B. Mangifera sp.2 (Hutan) dose 2; C. Mangifera sp.2 (Hutan) dose 3; D: $M$. sumatrana dose 1 ; E. $M$. sumatrana dose $2 ;$ F. $M$. sumatrana dose 3 ; G. $M$. foetida (var. Batu) dose 1; H. M. foetida (var. Batu) dose 2; I. M. foetida (var. Batu) dose 3. a: Glomelurus, b: Bowman capsule, c: pycnosis core

\section{CONCLUSION}

The damage that occurs to the kidneys is still small and in the normal range, less than $25 \%$. The results of this study provide information that the consumption of Sumatran wild mango extract does not cause toxicity effects on the rats' kidneys.

\section{ACKNOWLEDGMENT}

The author would like to thank the Directorate of Research and Community Service-Ministry of Research Technology and Higher Education (Kemenristekdikti) with contract number 731/UN.19.5.1.3/PT.01.03 /2020 for providing funding for this research.

\section{REFERENCES}

[1] M.F. Schreuder, R.R. Bueters, M.C. Huigen, F.G.M. Russel, R. Masereeuw, L.P. van-den Heuvel, Effect of drugs on renal development, Clinical Journal of the American Society of Nephrology 6(1) (2011) 212-217. DOI: http://dx.doi.org/10.2215/CJN.04740510

[2] S.A. Price, L.M. Wilson, Patofisiologi: Konsep klinis proses-proses penyakit, EGC, Jakarta, 2012. [In Bahasa Indonesia]

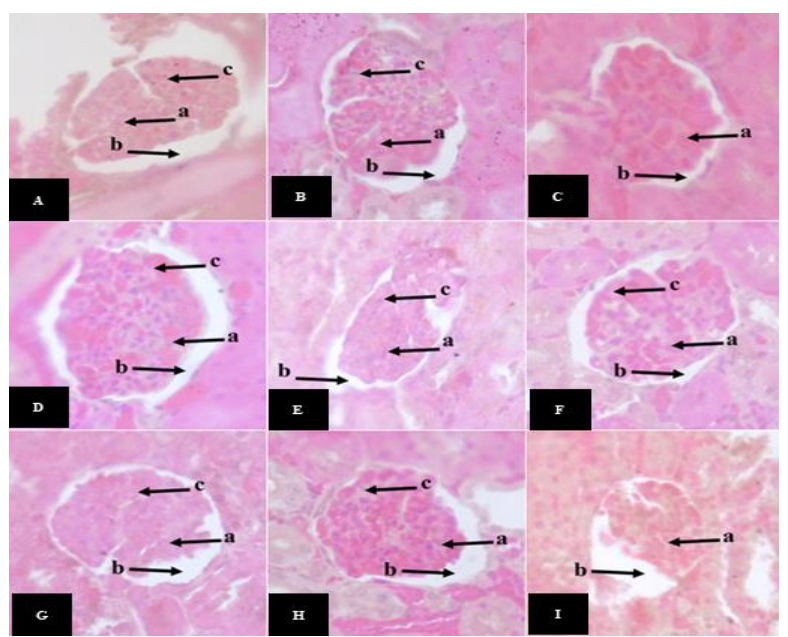

Figure 6. Histologic Structure of the White Rat $(R$. novergicus) kidney. Hematoxylin-Eosin Staining. Magnification 400x A. Mangifera foetida (var. Limus) dose 1 ; B. $M$. foetida (var. Limus) dose 2; C. $M$. foetida (var. Limus) dose 3 ; D. M. foetida (var. Manis) dose 1; E. $M$. foetida (var. Manis) dose 2; F. $M$. foetida (var. Manis) dose 3; G. M.laurina dose 1; H. M. laurina dose 2; I. M.laurina dose 3. a: Glomelurus, b: pycnosis core, c: pycnosis core

[3] F.C. Lu, Toksikologi Dasar; Asas, organ sasaran, dan penelitian resiko. Edisi ke-2. UI Press, Jakarta, 1995. [In Bahasa Indonesia]

[4] BPOM RI, Pedoman uji toksisitas nonklinik secara in vivo, Pusat Riset Obat dan Makanan Jakarta, 2011. [In Bahasa Indonesia]

[5] S.N. Kholifah, Fitmawati, Efektivitas imunomodulator ekstrak daun macang (Mangifera foetida L.) terhadap sel makrofag tikus putih (Rattus norvegicus), Jurnal Matematika dan Ilmu Pengetahuan Alam 11(1) (2020) 130-141. DOI: http://dx.doi.org/10.26418/jpmipa.v11i1.32763. [In Bahasa Indonesia]

[6] D. Krishnaiah, R. Sarbatly, R. Nithyanandam R, A review of the antioxidant potential of medicinal plant species, Food and Bioproducts Processing 89(3) (2011) 217-33. DOI: http://dx.doi.org/10.1016/j.fbp.2010.04.008

[7] Fitmawati, E. Resida, S.N. Kholifah, R.M. Roza, M. Almurdani, Emrizal, Phytochemical screening and antioxidant profiling of Sumatran wild mangoes (Mangifera spp.): a potential source for medicine antidegenerative effects, F1000Research 9(220) (2020). DOI: http://dx.doi.org/10.12688/f1000research.22380. 3 
[8] F. Luo, L. Qiang, Y. Zhao, G. Hu, G Huang, Quantification and purification of mangiferin from Chinese mango (Mangifera indica L.) cultivars and its protective effect on human umbilical vein endothelial cells under H2O2-induced stress, International Journal of Molecular Sciences 13(9) (2012) 11260-11274. DOI: https://doi.org/10.3390/ijms130911260

[9] G.L. Pardo-Andreu, B.A. Paim, R.F. Castilho, J.A. Velho, R. Delgado, Mangifera indica L. extract (Vimang) and its main polyphenol mangiferin prevent mitochondrial oxidative stress in atherosclerosis-prone hypercholesterolemic mouse, Pharmacological Research 57(5) (2008) 332-338. DOI: https://doi.org/10.1016/j.phrs.2008.03.005

[10] N. Wauthoz, B.A. Aliou, E.S. Balde, M. vanDamme, P. Duez, Ethnopharmacology of Mangifera indica L. bark and pharmacological studies of its main C-glucosylxanthone, Mangiferin, International Journal of Biomedical and Pharmaceutical Sciences 1(2) (2007) 112119.

http://www.globalsciencebooks.info/Online/GS BOnline/images/0712/IJBPS_1(2)/IJBPS_1(2)1 12-119o.pdf

[11] A.Z.I. Baldatina, Pengaruh pemberian insektisida (esbiothrin, imiprothrin, dan dpenothrin) pada tikus putih (Rattus rattus): Kajian hispatologi hati dan ginjal, Fakultas Kedokteran Hewan ITB, Bandung, 2008. [In Bahasa Indonesia]

[12] N. Assiam, S. Iriani, K.S. Sang, Pengaruh dosis dan lama perlakuan ekstrak daun kaliandra merah (Calliandra calothyrus Meissn.) terhadap struktur histologi ginjal mencit (Mus musculus L.), Jurnal Simbiosis: Journal of Biological Sciences 2(2) (2014) 236-246. https://ojs.unud.ac.id/index.php/simbiosis/article /view/9782. [In Bahasa Indonesia]

[13] L. Sherwood, Human physiology: from cells to systems, Cengage learning, 2015.

[14] Casarett, Doull's, In: D.Klassen C, Toxicology: the basic Science of Poisons. VII ed, United State of America: TheMcGraw-Hill Companies, 2008.

[15] R.S. Snell, Anatomi klinik untuk mahasiswa kedokteran. Ed ke-6. EGC, Jakarta, 2006. [In Bahasa Indonesia]

[16] Syaifuddin, Anatomi Fisiologi untuk Mahasiswa Keperawatan, EGC, Jakarta, 2003. [In Bahasa Indonesia]
[17] J.L. Khakim, Pengaruh jus buah pepaya (Carica papaya) terhadap kerusakan histologi lambung mencit yang diinduksi aspirin, Universitas Sebelas Maret, Surakarta, 2007. [In Bahasa Indonesia]

[18] O. Sanchez, A. Arnau, M. Pareje, E. Poch, I. Ramirez, M. Soley, Acute stress induced tissue injury in mice; different between emotional and social stress, Cell Stress Society International, 50(3) (2002) 182-119. DOI: http://dx.doi.org/10.1379/14661268(2002)007\%3C0036:ASITII\%3E2.0.CO;2

[19] Y. Sulistyowati, I. Setyobroto, R. Anggiana, R. Pratiwi, Pengaruh pemberian ekstrak air herba ciplukan (Physalis angulata L.) terhadap histologi ginjal tikus galur Sprague Dawley Hiperglikemia, Prosiding Seminar Nasional 2013 Menuju Masyarakat Madani Dan Lestari, 2013, pp. 461-468. [In Bahasa Indonesia]

[20] S. Septiana, R. Kurniati, Pengaruh pendedahan ekstrak batang tabar kedayan (Aristolochia papillfolia Ding Hou) terhadap struktur jaringan ginjal mencit (Mus musculus L.), Bioprospek 6(2) (2009) 16-22. [In Bahasa Indonesia]

[21] A.Susilo, A. Ismail, Pengaruh pemberian metanil yellow peroral dosis bertingkat selama 30 hari terhadap gambaran histopatologi ginjal mencit Balb/c, Jurnal Kedokteran Diponegoro 3(1) (2014) 1-16. [In Bahasa Indonesia]

[22] N.L.P.R Suhita, I.W. Sudira, I.B.O. Winaya, Histopatologi ginjal tikus putih akibat pemberian ekstrak pegagan (Centella asiatica) per Oral, Buletin Veteriner Udayana 5(2) (2013) 71-78.

DOI: https://doi.org/10.21157/jim\%20vet..v4i4.15716 [In Bahasa Indonesia]

[23] Robbins, Robbins and Cotran Pathologic basis of diseases, Seventh edition, Elsevier Inc. Philadedlphia, 2007.

[24] R. Mayori, N. Marussin, D.H. Tjong, Pengaruh pemberian rhodamin $\mathrm{b}$ terhadap struktur histologi ginjal mencit putih (Mus musculus L.), Jurnal Biologi Universitas Andalas 2(1) (2013) 43-49.

DOI: https://doi.org/10.25077/jbioua.2.1.\%25p.2013. [In Bahasa Indonesia] 